\title{
The Problems of Halal Certification Regarding Consumer Protection in Malaysia and Indonesia
}

\author{
Ratna Sofiana $\mathrm{a}^{*}$, Satria Utama ${ }^{\mathrm{b}}$, Abdur Rohim ${ }^{\mathrm{C}}$ \\ a Universitas Islam Negeri Sunan Kalijaga, Yogyakarta, Indonesia \\ bUniversitas Muhammadiyah Yogyakarta, Indonesia \\ 'Universitas Kebangsaan Malaysia, Malaysia \\ Corresponding author: ratnasofiana@uin-suka.ac.id*
}

\section{ARTICLE INFO}

\section{Article history}

Received: August 5, 2021

Revised: August 30, 2021

Accepted: September 5, 2021

\section{Keywords}

Certification;

Halal;

Indonesia;

Malaysia

\section{ABSTRACT}

Halal certification is a form of the State's protection for Muslim society. Malaysia and Indonesia are two Muslim-majority countries. These two countries are concerned about providing a guarantee for the right of their people to obtain foods, drugs, and cosmetics following their Islamic beliefs. Therefore, they are to ensure halal certification as part of the efforts. In order to scrutinize the two countries' policies on halal products, this article aims to explore the problems of halal certification on consumer protection they face. This study applies a comparative approach. Data were collected by literature study in the related topics. The findings of this study conclude that, in terms of governance systems, halal certification performed by Malaysia is more organized and systematic than by Indonesia. The law enforcement of the Republic of Indonesia, compiled in Omnibus Law 2020, has a positive impact on the halal certification processes. However, it is not an appropriate guarantee of excellent governance systems due to its status after the decision of the Constitutional Court in 2020, which suspended the constitutionality of this Omnibus Law.

This is an open-access article under the CC-BY 4.0 license.

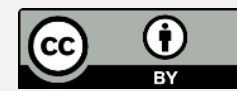

\section{Introduction}

Halal certification is one of the state protections for society, especially Muslims. Halal is an attractive global trend for many countries today. ${ }^{1}$ It not only attracts the countries with the majority of Muslims, but it also attracts the countries where the Muslims are a minority. This means that the existence of Muslims becomes a concern in this increasingly advanced, developing, and dynamic industrialization

${ }^{1}$ Komite Nasional Keuangan Syariah, Masterplan Ekonomi Syariah Indonesia 2019-2024, Kementerian Perencanaan Pembangunan Nasional/ Badan Perencanaan Pembangunan Nasional (Jakarta, 2018) https://knks.go.id/storage/upload/1573459280-Masterplan Eksyar_Preview.pdf 
era. It also makes the fundamental obedience among Muslims, one of them is about food law. ${ }^{2}$

The 2018-2019 Global Islamic Economic Report noted that the number of Muslims globally was more than 87.18 percent of 232.5 million people. Reflecting on the high number of Indonesian Muslim population reaching more than $87 \%$ or noted to be a significant majority, the State must enact and guarantee various regulations for the rights of the existing Muslim community. This is a step and an effort taken by the State, which has an obligation to provide guarantee and protection to society and every religious compliance, so they can keep performing the worship safely and conveniently and can also be able to practice their religious values.

Food is a primary need that must be fulfilled since it is not only about how to get it, but it also starts from the ingredients, process, and how the food is made. Moreover, it is important to consider the halal status of products consumed and used by the community. As a country with a large Muslim population, Indonesia can become the center of the world's Islamic economy. ${ }^{3}$ This is based on Indonesia's potential, especially those related to the halal industry. ${ }^{4}$ The population and potential of Indonesian Muslims are significant and continue to grow, causing a sizeable halal market to expand as well. ${ }^{5}$ Based on data from the Indonesian Information Portal, the percentage of the current Muslim population is approximately $87 \%$ of the total population, with approximately 207 million people. Other religious believers, such as Protestant Christians, reach 6.9\%, Catholic Christians with a percentage of $2.9 \%$, Hindus with a percentage of $1.7 \%$, Buddhists with a percentage of $0.7 \%$, and Confucianists with a percentage of $0.05 \%$.

The halal status of a product is currently a necessity and mandatory for every consumer, especially Muslim consumers. ${ }^{6}$ Therefore, the existence of an institution that can guarantee halal status is an inevitable and absolute urgency in providing halal certification for Muslim consumers. As a form of the State's presence in guaranteeing the right of its people to obtain foods, drugs, and cosmetics

${ }^{2}$ Agus Triyanta, Ni'matul Huda, and R Nazriyah, Hukum Ekonomi Islam: Dari Politik Hukum Ekonomi Islam Sampai Pranata Ekonomi Syariah (Yogyakarta: FH UII Press, 2012). Google Scholar

${ }^{3}$ Devi Triasari and Francesco De Zwart, 'The Legal Reform Policy on the Shariah Supervisory

Board Role's in Indonesian Shariah Banks', Bestuur, 9.2 (2021), 113-25 https://dx.doi.org/10.20961/bestuur.v9i2.55173

${ }^{4}$ Mahiah Said and others, 'Assessing Consumers' Perception, Knowledge and Religiosity on Malaysia's Halal Food Products', Procedia-Social and Behavioral Sciences, 130 (2014), 120-28 https://doi.org/10.1016/j.sbspro.2014.04.015

5S Rohmah, 'The Pattern of Absorption of Islamic Law into National Law: Study of the Halal Product Guarantee Law in the Perspective of Maqashid Shari'ah', Jurisdictie, 12.1 (2021), 20-47 https://doi.org/10.18860/j.v12i1.10521

${ }^{6}$ M. Jamil, 'Fiduciary Security Arrangements and Issues in Indonesia', Journal of Human Rights, Culture and Legal System, 1.2 (2021), 109-19 https://doi.org/10.53955/jhcls.v1i2.1 
according to their beliefs, such effort is crucial to make the Muslim population convenient in getting goods that follow the demands of Islamic law. ${ }^{7}$

The regulations and guidelines in Islamic law require a syar'i process in everything that is lawful and thoyib, starting from materials, products, product processing to the final process. Even long before this regulation existed, the state constitutionally issued the mandate of Law No. 33/2014 on Halal Product Guarantee as to the manifestation and responsibility of the State, which will always be present in providing protection for people's rights for getting a healthy and protected life in worship according to the values of religion as stipulated in the 1945 Constitution.

The halal status of a product is generally a concern of Muslim consumers, but with increasing awareness of health, halal products have enormous potential to be marketed, even in non-Muslim markets. Research results from Mathew (2013) recommended the non-Muslim market share as one of the potential targets of the halal industry. ${ }^{8}$ Research by Yunos (2013) related to the perception of the Indonesian Small Medium Enterprises (SMEs) actors towards halal certification shows that producers who have a good literacy level are willing to apply for halal certification for their products. ${ }^{9}$ Research conducted by Rusydiana (2020) also found that there is an increasing awareness of halal certification globally, so stakeholders must take advantage of this momentum in encouraging economic revival and ensuring consumer protection. ${ }^{10}$ Regarding the context of consumer protection, research conducted by Halim (2014) emphasized that the government is responsible for protecting consumers from all forms of fraud and fraud in halal products. ${ }^{11}$ Therefore, it is crucial for the government to ensure that the current regulations are fully enforced, and if there are breaches in the regulations, they should be reviewed and amended. This will ensure an efficient and effective set of regulations for the maximum optimization of consumer protection.

This research has a significant contribution since Indonesia's existing halal assurance standards are still left behind compared to other Muslim countries, especially Malaysia, which has been well organized and systematic. The notion related to halal certification in the Omnibus Law gives new hope for a better system that can guarantee the rights of Muslim consumers. Therefore, it is significant to conduct a comparative study of the problems of halal certification in

7Triyanta, Huda, and Nazriyah. Google Scholar

8 Vloreen Nity Mathew, 'Acceptance on Halal Food among Non-Muslim Consumers', ProcediaSocial and Behavioral Sciences, 121 (2014), 262-71. https://doi.org/10.1016/j.sbspro.2014.01.1127

9 Rahimah Mohamed Yunos, Che Faridah Che Mahmood, and Nor Hafizah Abd Mansor, 'Understanding Mechanisms to Promote Halal Industry-the Stakeholders' Views', Procedia-Social and Behavioral Sciences, 130 (2014), 160-66. https://doi.org/10.1016/j.sbspro.2014.04.020

10 Aam Slamet Rusydiana and Lina Marlina, 'Analisis Sentimen Terkait Sertifikasi Halal', JEBA (Journal of Economics and Business Aseanomics), 5.1 (2020). https://doi.org/10.33476/j.e.b.a.v5i1.1405

${ }^{11}$ Mustafa'Afifi bin Ab Halim and others, 'Consumer Protection of Halal Products in Malaysia: A Literature Highlight', Procedia-Social and Behavioral Sciences, 121 (2014), 68-78. https://doi.org/10.1016/j.sbspro.2014.01.1109 
the context of Muslim consumer protection in Malaysia and Indonesia after enacting the work copyright law. Based on the explanation above, this article gives several answers for the research problems, i.e., how to compare the problems of halal certification regarding Muslim consumer protection in Malaysia and Indonesia after the enactment of the Omnibus Law?

\section{Research Method}

The authors used a literature study by employing secondary data in the form of primary, secondary, and tertiary legal materials. The primary legal materials included laws and regulations relating to the halal status of foods and beverages. The secondary legal materials consisted of books and/or opinions of legal experts related to the protection of consumer rights. This study was qualitative research with a normative juridical nature. The data obtained from the results of library research were analyzed systematically and scientifically to answer the research problems.

\section{Results and Discussion}

\subsection{Muslim Consumer Protection through Halal Certification and Labeling}

It has become an international regulation that the circulation of consumer foods, drugs, and cosmetics must meet safety standards to use. This is in line with the thoyib principle. Even the Covid-19 vaccine, which is currently circulating in the community, must also provide halalan thayiban guarantee. Therefore, the urgency of having halal certification for the food, fashion, and cosmetics is a form of protection that the State must provide to its people. The term "halal" derives from the words halla, yahillu, hillan which means "liberating," "releasing," "solving," "dissolving," and "permitting." If it is seen from the definition, the word "halal" can be understood and related to the meaning of "permissibility" for a Muslim to consume and/or use various objects, both for physical and non-physical purposes, in the form of foods, drugs, fashions, plants, and so on. ${ }^{12}$

The legal terms of the obligation to guarantee halal products according to Islamic law are mentioned in "QS. Al-Baqarah: 168", "QS. Al-Baqarah: 172", and "QS. Al-Baqarah: 173 '. One's level of religiosity can also affect consumer orientation (Said, Hassan, Musa, \& A, 2014) where consumers will consider buying or consuming products that do not violate or conflict with their beliefs. It is the same as the case of Muslim consumers who only consume halal (permitted or allowed) and Tayyib (clean) food following Islamic religious values in the Al-Quran, i.e., Surah Al-Baqarah: $172 .{ }^{13}$ The concept of halal refers to something permissible in Islam. ${ }^{14}$

${ }^{12}$ Mohd Zaid Mustafar and Joni Tamkin Borhan, 'Muslim Consumer Behavior: Emphasis on Ethics from Islamic Perspective', Middle-East Journal of Scientific Research, 18.9 (2013), 1301-7. https://doi.org/10.5829/idosi.mejsr.2013.18.9.12113

${ }^{13}$ Abdul Raufu Ambali and Ahmad Naqiyuddin Bakar, 'People's Awareness on Halal Foods and Products: PPotential Issues for Policy-Makers', Procedia-Social and Behavioral Sciences, 121 (2014), 3-25. https://doi.org/10.1016/j.sbspro.2014.01.1104

${ }^{14}$ Nader Al Jallad, 'The Concepts of Al-Halal and Al-Haram in the Arab-Muslim Culture: A Translational and Lexicographical Study', Language Design: Journal of Theoretical and Experimental Linguistics, 10.1 (2008), 77-86. Google Scholar 
As a Muslim who is biddable and obedient to God's commands, i.e., people who believe in consuming halal food and thayib. Besides, it is also not allowed to consume food and goods included in the gray area category. A gray area is regarded as a fine line between Halal and Halal. Therefore, it becomes very important to maintain certainty on what we consume. A little bit of Halal is worried to contaminate things that should be halal and then become Halal. Also, there is a position with a very thin level of distinction between Halal and Halal, or the category of syubhat (dim-lit), and thus, we must first make sure that we need halal certification. The halal certification will be a guarantee that what we consume is halal. For that reason, it requires a certainty from the State to provide a halal certification guarantee so that it becomes a clear area.

There is also a stipulation that all types of food and drinks that will be circulated to the public must also have a "halal certificate" logo that has been tested and issued by the Indonesian Council of Ulama on the product packaging ${ }^{15}$. A Muslim who consumes halal-certified food is believed to be able to improve her/his experience in terms of food consumption in the current contemporary era. The necessity for a basic halal certification, which lies in the food we consume today, is not all of which we take directly from nature. We have encountered a lot of contamination and intervention in the presentation of food e.g., when consuming bananas. There is no need for halal certification. However, when the banana processing has been made, it must be clear for its halal status, and there must be a guarantee of the halal status, such as the ingredients and procedures. There will be technological intervention in the processing that will then change the original characteristics, and thus, it is important to have halal certification.

The processed bananas must be tested in a laboratory for inspection of raw materials, processes, locations, and organizational structures. At present, the authority to issue a "halal certificate" has shifted to the "Halal Product Assurance Management Agency," or known as Badan Pengelola Jaminan Produk Halal (BPJPH), from the previous authority by the Indonesian Council of Ulama. Based on history, John F. Kennedy, the late president of the United States of America, was the first one to highlight the idea of consumer protection for the public through the Declaration of Consumer Rights. This declaration was submitted to the US Congress on March 15, 1961. There were four basic rights declared: right to safety, right to be notified, right to vote, right to be heard. ${ }^{16}$

The concept of consumer rights was then expanded to include other rights as stated by Anwar Fazal, the President of International Organization of Consumers Unions (IOUC), including right to the fulfillment of primary needs, right to a healthy environment, right to compensation, right to consumer education, right to representation. ${ }^{17}$ To protect the consumers from profit-seeking actions of producers and sellers, there have been various policies, laws, and plans introduced by governments of many countries, world organizations, and consumer organizations at national and international levels, such as the United Nations Guidelines for Consumer Protection, the EU Consumer Policy

${ }^{15}$ Hijrah Lahaling, Kindom Makkulawuzar, and Singkeru Rukka, 'Hakikat Labelisasi Halal Terhadap Perlindungan Konsumen Di Indonesia', Hasanuddin Law Review, 1.2 (2015), 282. https://doi.org/10.20956/halrev.v1n2.84

${ }^{16} \mathrm{~A} H \mathrm{H}$ Mustafa'Afifi and others, 'Consumer Protection of Halal Products in Malaysia', MiddleEast Journal of Scientific Research, 13 (2013), 22-28. https://doi.org/10.5829/idosi.mejsr.2013.16.s.10025

${ }^{17}$ Mustafa 'Afifi Ab. Halim and Mohd Mahyeddin Mohd Salleh, 'The Possibility of Uniformity on Halal Standards in Organization of Islamic Countries (OIC)', World Applied Sciences Journal, 17 (2012), 6-10. Google Scholar 
Strategy (2007 - 2013), the Regulation (EU) on Consumer Protection Cooperation, ASEAN Economic Community (AEC) Blueprint, and Consumer Basic Act (Japan). ${ }^{18}$

The issue of halal certification is an absolute must. There was a problem with the legalization of liquor or alcohol, which incidentally is included in the category of Halal food in Indonesia. This led to a long polemic until the policy of legalizing liquor was finally revoked by President Joko Widodo. It indicates that halal status is very important in Indonesia. Halal certification has also received world attention in ASEAN-AFTA, NAFTA, EEC, and WTO in the current international trade system. ${ }^{19}$ The halal certification has long been implemented in international trade that is familiar with the halal provisions. Halal is a global trend that is attracting the attention of many countries today. ${ }^{20}$ It is presented in Muslim countries and in countries with non-Muslim majority populations who currently implement a halal system. Several international airlines have provided Moslem Meal services, such as Japan Airlines, Qantas, and American Airlines. "halal" has now become a lifestyle that is echoed throughout the world.

The word "halal" in Islam means something that Muslims can consume, ${ }^{21}$ not only in food but also in all aspects of products and services. ${ }^{22}$ Meanwhile, the halal certification represents product quality according to the Islamic sharia standards. According to Islamic values, the halal certification is used as a consumption guideline by Muslims. ${ }^{23}$ Islam has special concepts and principles in terms of muamalat which refer to the Qur'an and alHadith that are absolute as that of the principles of at-tawhid, al-adal, al-maslahat, and so on. Therefore, the regulation and certification of halal consumption products and cosmetics have an important role as a form of consumer protection in general and Muslim consumers in particular.

The presence of a clean and clear guarantee of food in terms of good or bad food is important for Muslims to always pay attention to the products they consume to be guaranteed for its Halal status. ${ }^{24}$ One of the elements in the halal concept is a halal lifestyle which focuses more on a person's way of life, which is all regulated by Islam. The halal lifestyle has now become a global concern over time. ${ }^{25}$ The concept may be applied in all aspects of life. The halal lifestyle includes halal consumption products, tourism,

${ }^{18}$ Mustafa 'Afifi Ab. Halim and Mohd Mahyeddin Mohd Salleh. Google Scholar

${ }^{19}$ Rizky Irfano Aditya and Lisa Waddington, 'The Legal Protection Against Child Marriage in Indonesia', Bestuur, 9.2 (2021), 126-34. https://dx.doi.org/10.20961/bestuur.v9i2.55144

${ }^{20}$ Komite Nasional Keuangan Syariah. https://knks.go.id/storage/upload/1573459280-Masterplan Eksyar_Preview.pdf

${ }^{21}$ Joan C Henderson, 'Halal Food, Certification and Halal Tourism: Insights from Malaysia and $\begin{array}{llllll}\text { Singapore', } \quad \text { Tourism } & \text { Management } & \text { (2016), 160-64. }\end{array}$ https://doi.org/10.1016/j.tmp.2015.12.006

${ }^{22}$ Mehdi Rejaii and Akram Arianfar, 'Halal Food: A Systemic Review', International Journal of PharmTech Research, 9.7 (2016), 340-45. Google Scholar

${ }^{23}$ Nazlida Muhamad, Vai Shiem Leong, and Normalisa Md Isa, 'Does the Country of Origin of a Halal Logo Matter? The Case of Packaged Food Purchases', Review of International Business and Strategy, 2017. https://doi.org/10.1108/RIBS-06-2017-0049

${ }^{24}$ Ramlan Ramlan and Nahrowi Nahrowi, 'Sertifikasi Halal Sebagai Penerapan Etika Bisnis Islami Dalam Upaya Perlindungan Bagi Konsumen Muslim', AHKAM : Jurnal Ilmu Syariah, 17.1 (2014), 145-54. https://doi.org/10.15408/ajis.v17i1.1251

${ }^{25}$ Nurul Izza Abdul Aziz and Fadzila Azni Ahmad, 'The Halal Lifestyle of Muslim Working Women', International Journal of Academic Research in Business and Social Sciences, 8.5 (2018), 1138-47. https://doi.org/10.6007/IJARBSS/v8-i5/4489 
pharmaceuticals, cosmetics, fashion, and financial services. ${ }^{26}$ However, several studies have applied it to food (halal food), such as Nity, Mazwa, \& Abdullah (2014), ${ }^{27}$ Raufu \& Naqiyuddin (2014), ${ }^{28}$ Said, Hassan, Musa, \& A (2014), ${ }^{29}$ Wahyu \& Sheikh (2016), ${ }^{30}$ and Marini, Alia, \& Haron (2014). ${ }^{31}$

The present standardization and certification process used as a benchmark if a product is considered proper for market circulation does not stop at the Halal and halal levels, regardless of the raw material process, the process, the place, and the existing organizational structure. It also excludes how technological intervention plays a role in changing origin characteristics, in which halal certification is important. Furthermore, halal certification refers to food consumed by a Muslim and halal as a means of safe and proper consumption. The halal certification is considered an important factor that increases consumer confidence that the products are halal, safe, and clean. It does not only imply the meaning of halal, but it also emphasizes halal as kaffah, i.e., hallan thayyiban. It is different from the context of looking for Halal products since it will be easier to track and identify them. If the raw material is included in the category of Halal to eat, it will make the product Halal without having to do a laboratory test first.

The word "halal" is generally defined as a case or act that is "permissible," "permitted," or "allowed" by Islamic law, while Halal is a matter or act that is "forbidden" by Islamic law. It also means something that is "forbidden," with the concepts of prohibition originating from things that have been regulated in Islamic law. ${ }^{32}$ The present concept of "halal" or "halal lifestyle" certification is not only offered and intended by Muslims, but it has also become a concern for non-Muslims who are currently emerging as a global issue. The Muslim market share has become a tantalizing thing, not only for Muslim countries but also for several non-Muslim countries globally, including Western countries, who are also very concerned about this issue. Opportunities must be followed by challenges which become a correlation that must be faced. For this reason, the State (i.e., the government) has the task of being able to implement an independent, prosperous, and civilized Indonesian state by being able to make Indonesia a capable center of sharia economy in the world.

${ }^{26}$ Komite Nasional Keuangan Syariah. https://knks.go.id/storage/upload/1573459280-Masterplan Eksyar_Preview.pdf

${ }^{27}$ Ardiana Mazwa Raudah Amir Abdullah and others, 'Dimensions Necessitated for Total Service Operations Management (TSOM)', 2014. Google Scholar

${ }^{28} \mathrm{~A}$ Raufu and A Naqiyuddin, 'People's Awareness on Halal Foods and Products', Social and Behavioral Sciences, 2014, 3-25. https://doi.org/10.1016/j.sbspro.2014.01.1104

29Said and others. https://doi.org/10.1016/j.sbspro.2014.04.015

${ }^{30}$ Mas Wahyu Wibowo and Fauziah Sheikh Ahmad, 'Non-Muslim Consumers' Halal Food Product Acceptance Model', Procedia Economics and Finance, 37 (2016), 276-83. https://doi.org/10.1016/S2212-5671(16)30125-3

${ }^{31}$ Nor Marini Mohtar, Nur Alia Amirnordin, and Hazliza Haron, 'Ayamas Food Corporation Sdn. Bhd: A Study on the Factors of Consumer Behaviour towards Halal Product Selection', $\begin{array}{lllll}\text { Procedia-Social and Behavioral } & \text { Sciences, } & 121 & \text { (2014), } & \text { 166-85. }\end{array}$ https://doi.org/10.1016/j.sbspro.2014.01.1118

${ }^{32}$ Mardani Mardani, 'Hukum Islam Dalam Sistem Hukum Nasional', Jurnal Hukum \& Pembangunan, 2008. https://doi.org/10.21143/jhp.vol38.no2.170 


\subsection{The Problems of Halal Certification in Protecting Consumers}

Not to remain silent, the government is also responsive to halal issues in Indonesia, especially those concerning foods, drugs, and cosmetics, by issuing several regulations. However, the legal drafting of the regulations was prepared partially and inconsistently, so it became contradictory and was neither systemic nor systematic. Therefore, the regulation is not yet relevant to be used as a strong legal basis and is binding on the problem of the halal status of a product to producers (business actors) and guarantees of convenience to consumers. ${ }^{33}$ Having provided with such a dynamic, there is no guarantee of legal certainty related to halal products, even though the urgency of the presence of halal product certification is an absolute and very urgent thing, especially those related to consumer protection references and the need for standards for today's global trade.

The presence of Omnibus Law is expected to facilitate the halal certification process in Indonesia. This can be seen from the shift of the authority for halal certification from THE Institute for Foods, Drugs, and Cosmetics, the Indonesian Council of Ulama, to the Halal Product Guarantee Agency, which is directly organized under the government. In the future, based on the existing law, it is possible to form private halal certification institutions that become an extension of the hand of the halal certification process from the Halal Product Guarantee Agency. In the end, all producers, whether on a big or small-medium scale, will find it easier to access the halal certification process, which becomes the need of consumers and consumer protection. Meanwhile, Malaysia's certification authority is currently performed through the Development and Progress of Islamic Affairs or commonly known as JAKIM, and no regulation allows private institutions to do so.

There are 22 articles of Law No. 33/2014 on halal inspection agency which have been amended in the Omnibus Law. Besides, two new articles include provisions relating to the halal certification business process, halal product guarantee agency cooperation, halal inspection agency, halal auditor, Halal Supervisor, Community Participation, Halal Certificate, and Halal Label Self-Declaration, and Administrative Sanctions. Also, the halal certification becomes consumer protection and consumer understanding regarding halal products. For business actors, halal certification is their responsibility in making their products. ${ }^{34}$ According to Nasution et al. (2018), ${ }^{35}$ the country of origin of halal certification affects the purchase intention of the imported food. Meanwhile, W. Khan, Akhtar,

\footnotetext{
${ }^{33}$ Rachel Georghea Sentani and Mathijs ten Wolde, 'The Legal Policy of Executability in the International Arbitral Tribunal Decision', Bestuur, $9.2 \quad$ (2021), 144-55. https://dx.doi.org/10.20961/bestuur.v9i2.54451

${ }^{34}$ Halim and others. https://doi.org/10.1016/j.sbspro.2014.01.1109

${ }^{35}$ Muhammad Dharma Tuah Putra Nasution and Yossie Rossanty, 'Country of Origin as a Moderator of Halal Label and Purchase Behaviour', Journal of Business and Retail Management Research, 12.2 (2018). https://doi.org/10.24052/JBRMR/V12IS02/COOAAMOHLAPB
} 
Ansari, \& Dhamija (2020) stated that halal certification is one of the driving forces for buying interest. ${ }^{36}$ Moreover, Hamdan, Issa, Abu, \& Jusoff (2013) stated that the awareness of halal certification affects buying interest. ${ }^{37}$ Such a condition shows that halal certification leads to halal awareness of consumers and producers. Ambali \& Bakar (2014b) found that halal certification is an antecedent of halal awareness. ${ }^{38}$ Besides, Pradana, Huertas-García, \& Marimon (2020) stated that halal certification affects the tourists' buying interest in Spain. ${ }^{39}$

The enactment of Law No. 33/2014 on Halal Product Guarantee aims to emphasize the urgency of the issue of halal assurance in the production and distribution chain from producers to consumers, where the distribution chain will involve other intermediaries, such as the distributors, sub-distributors, wholesalers, and retailers before arriving at the final consumers as a user. The law's enactment aims to give the consumers legal certainty for the products they want to buy. As for business actors, the presence of the law is a "technical guide" on how to "process," "produce," and "market" the products to the consumers as well as how to create and convey information on halal product guarantee to the consumers an as user.

The absolute existence of halal certification is enshrined in Law No. 33/2014, which regulates "halal product guarantee." It contains all obligations for all types of products that will be circulated in the territory of the Republic of Indonesia, which must have a halal certificate and halal logo on the packaging unless it is clear that there is "not halal" information therein. Another regulation in this also aims to establish a "Halal Product Guarantee Agency" in which the agency has the authority to "formulate" and "stipulate" various policies regarding halal product guarantees, norms, standards, procedures, and anything that is included in the criteria for halal product guarantees. ${ }^{40}$ The other authorities are being able to "issue" and "revoke" halal certificates, "give the halal label" on products, "register halal certificates on imported products," "accredit existing halal inspection institutions," "register halal auditors," "supervise halal product guarantees," "foster halal auditors", and "cooperate" with domestic and foreign institutions in implementing halal product guarantees.

${ }^{36}$ Waseem Khan and others, 'Enablers of Halal Food Purchase among Muslim Consumers in an Emerging Economy: An Interpretive Structural Modeling Approach', British Food Journal, 122.7 (2020), 2273-87. https://doi.org/10.1108/BFJ-08-2018-0528

${ }^{37}$ Haslenna Hamdan and others, 'Purchasing Decisions among Muslim Consumers of Processed Halal Food Products', Journal of Food Products Marketing, 19.1 (2013), 54-61. https://doi.org/10.1080/10454446.2013.724365

${ }^{38} \mathrm{Ambali}$ and Bakar. https://doi.org/10.1016/j.sbspro.2014.01.1104

${ }^{39}$ Mahir Pradana, Rubén Huertas-García, and Frederic Marimon, 'Spanish Muslims' Halal Food Purchase Intention', International Food and Agribusiness Management Review, 23.2 (2020), 189-202. https://doi.org/10.22434/IFAMR2019.0200

${ }^{40}$ Andi Akbar Herman and Muhammad Jihadul Hayat, 'Management of High Secondary Education After Regional Government Law', Journal of Human Rights, Culture and Legal System, 1.2 (2021), 395-96. https://doi.org/10.53955/jhcls.v1i2.11 
The presence of the halal certification agency is conducive, especially for the Indonesian Muslim community. The process of implementing halal certification in Indonesia, which has been running significantly to date, will increasingly guarantee the benefit of the Indonesian Muslim community. This institution also plays a significant role in providing a guarantee and consumer protection in Indonesia, especially Muslims. As known and regulated in Law No. 8/1999 concerning Consumer Protection, especially Article 4 paragraph (a), explains "The consumer rights to have convenience, security, and safety in consuming goods and/or services." "Consumers also have the right to correct, clear, and honest information regarding the state and condition as well as guarantee for goods and/or services in Indonesia" 41

It can be concluded that the consumers must be given certain guarantees on how to obtain various necessities of life from the money they spend, meaning that it complies with the beliefs they hold, specifically Muslims, by making peace to get halalan thayyiban products. Before the enactment of Law 33/2004, the need for halal food was not specifically explained, but halal information is part of the information that must be explained ${ }^{42}$. However, the law's mandate concerning halal requires the government to provide a halal label and detail of the halal guarantee. ${ }^{43}$

To provide a commitment related to the halal industry, independence in providing halal certification can be seen from the "upstream" to the "downstream" process, including the halal value chain mechanism. The value chain will be created if the chains of all existing halal industry sectors can be interrelated, synergized, and take advantage of each other. The state must regulate the problems of halal certification through the presence of law and regulation to provide guarantees for the benefit and certainty of the existing products in Indonesia so that they can become a sharia economic center in the world. If it is drawn in the context of the halal industry, prosperity is the resource. How to use the existing resources and optimize the production and consumption of this industry by sharia values and principles is important, and thus, the process and the use of goods and services will provide the most significant benefit to both consumers and producers.

\subsection{Comparison of the Problems of Halal Certification between Indonesia and Malaysia}

Current regulations related to halal certification are only administrative requirements for producing and marketing a product. However, there is no precise mechanism regarding how the relevant authorities ensure that the product

\footnotetext{
${ }^{41}$ Republik Indonesia, ‘UU No 8 Tahun 1999 Perlindungan Konsumen', 2004, 1-6.

${ }^{42}$ Agus Triyanta, Hukum Ekonomi Islam; Dari Politik Hukum Islam Sampai Pranata Ekonomi Syariah, 2012. Google Scholar

${ }^{43}$ Mohd Rizal Palil and others, 'Social Enterprise and Taxation Policy: A Systematic Literature Review', Bestuur, 9.2 (2021), 135-43. https://dx.doi.org/10.20961/bestuur.v9i2.55569
} 
still meets halal standards when circulating in the community as certified. ${ }^{44}$ This is different from the regulations stipulated in Malaysia. Besides carrying out the certification process, some regulations ensure that the products still meet halal certification standards as long as the product is circulated in the market. ${ }^{45}$

There are also significant differences in the mechanism to ensure halal standards in each production process in which the Malaysian regulations require a halal manager or unit within a company who is responsible for ensuring that the production process always meet the halal certification standards, such as the role of internal financial auditors and quality assurance units in a company, or more specifically, the role of Sharia supervisory board Islamic financial institutions. The Malaysian halal standard supervision process does not yet exist in Indonesian regulations, especially in the Omnibus Law.

\section{Conclusion}

Halal certification is regarded as one of the state protections for its people. To get the right as a consumer to consume foods, drugs, and cosmetics originating from types and substances, the Muslim consumers are challenged with the condition to ensure the "halal" of a product, in addition to further and stricter regulations to be able to get the rights of Muslim consumers. The obedient Muslims are very concerned about the halal status of the products they consume. This signifies their compliance with their religious values and what is urgent to do, considering that not all Muslims understand whether the foods, drugs, cosmetic halal or not according to sharia law. Also, halal certification becomes consumer protection and understanding regarding halal products. In business actors, halal certification is their responsibility in making products. Besides, it needs education and affirmation to producers to prioritize the rights of Muslim consumers. As a country with the largest Muslim population globally, Indonesia Manufacturers also need to realize that halal certification and labeling are intended for the safety of Muslim consumers and have the potential to increase economic benefits for producers. The aspect of business ethics is also one of the points of view to address halal certification and labeling where producers maintain ethics to fulfill the rights of the Indonesian Muslims.

\section{References}

Aditya, Rizky Irfano, and Lisa Waddington, 'The Legal Protection Against Child Marriage in Indonesia', Bestuur, 9.2 (2021), 126-34. https://dx.doi.org/10.20961/bestuur.v9i2.55144

Ambali, Abdul Raufu, and Ahmad Naqiyuddin Bakar, 'People's Awareness on Halal Foods and Products: PPotential Issues for Policy-Makers', Procedia-Social and Behavioral Sciences, $121 \quad$ (2014), 3-25. https://doi.org/10.1016/j.sbspro.2014.01.1104

\footnotetext{
${ }^{44}$ Agus Hermawan, 'Consumer Protection Perception of Halal Food Products in Indonesia', in KnE Social Sciences, 2020, pp. 235-46. https://doi.org/10.18502/kss.v4i9.7329

${ }^{45}$ Asmuni Asmuni, M Jamil, and Fitri Rafianti, 'Dynamics of Application of Halal Certification on Medicine Products in Indonesia', Budapest International Research and Critics Institute (BIRCIJournal): Humanities and Social Sciences, 3.4 (2020), 2938-47. https://doi.org/10.33258/birci.v3i4.1314
} 
Amir Abdullah, Ardiana Mazwa Raudah, Firdaus Abdullah, Boo Ho Voon, Vloreen Nity Mathew, and Abg Hamizam Abg Mohar, 'Dimensions Necessitated for Total Service Operations Management (TSOM)', 2014.

Google Scholar

Asmuni, Asmuni, M Jamil, and Fitri Rafianti, 'Dynamics of Application of Halal Certification on Medicine Products in Indonesia', Budapest International Research and Critics Institute (BIRCI-Journal): Humanities and Social Sciences, 3.4 (2020), 2938-47. https://doi.org/10.33258/birci.v3i4.1314

Aziz, Nurul Izza Abdul, and Fadzila Azni Ahmad, 'The Halal Lifestyle of Muslim Working Women', International Journal of Academic Research in Business and Social Sciences, 8.5 (2018), 1138-47. https://doi.org/10.6007/IJARBSS/v8-i5/4489 Halim, Mustafa'Afifi bin Ab, Kamilah Wati binti Mohd, Mohd Mahyeddin Mohd Salleh, Asming Yalawae, Tuan Syed Mohd Najib Syed Omar, Asmidah Ahmad, and others, 'Consumer Protection of Halal Products in Malaysia: A Literature Highlight', Procedia-Social and Behavioral Sciences, 121 (2014), 68-78. https://doi.org/10.1016/j.sbspro.2014.01.1109

Hamdan, Haslenna, Zuraini Mat Issa, Normala Abu, and Kamaruzaman Jusoff, 'Purchasing Decisions among Muslim Consumers of Processed Halal Food Products', Journal of Food Products Marketing, 19.1 (2013), 54-61. https://doi.org/10.1080/10454446.2013.724365

Henderson, Joan C, 'Halal Food, Certification and Halal Tourism: Insights from Malaysia and Singapore', Tourism Management Perspectives, 19 (2016), 160-64. https://doi.org/10.1016/j.tmp.2015.12.006

Herman, Andi Akbar, and Muhammad Jihadul Hayat, 'Management of High Secondary Education After Regional Government Law', Journal of Human Rights, Culture and Legal System, 1.2 (2021), 395-96. https://doi.org/10.53955/jhcls.v1i2.11

Hermawan, Agus, 'Consumer Protection Perception of Halal Food Products in Indonesia', in KnE Social Sciences, 2020, pp. 235-46. https://doi.org/10.18502/kss.v4i9.7329

Al Jallad, Nader, 'The Concepts of Al-Halal and Al-Haram in the Arab-Muslim Culture: A Translational and Lexicographical Study', Language Design: Journal of Theoretical and Experimental Linguistics, 10.1 (2008), 77-86. Google Scholar

Jamil, M., 'Fiduciary Security Arrangements and Issues in Indonesia', Journal of Human Rights, Culture and Legal System, 1.2 (2021), 109-19. https://doi.org/10.53955/jhcls.v1i2.1

Khan, Waseem, Asif Akhtar, Saghir Ahmad Ansari, and Aruna Dhamija, 'Enablers of Halal Food Purchase among Muslim Consumers in an Emerging Economy: An Interpretive Structural Modeling Approach', British Food Journal, 122.7 (2020), 2273-87. https://doi.org/10.1108/BFJ-08-2018-0528

Komite Nasional Keuangan Syariah, Masterplan Ekonomi Syariah Indonesia 20192024, Kementerian Perencanaan Pembangunan Nasional/ Badan Perencanaan Pembangunan Nasional (Jakarta, 2018). 
https://knks.go.id/storage/upload/1573459280-Masterplan

Eksyar_Preview.pdf

Lahaling, Hijrah, Kindom Makkulawuzar, and Singkeru Rukka, 'Hakikat Labelisasi Halal Terhadap Perlindungan Konsumen Di Indonesia', Hasanuddin Law Review, 1.2 (2015), 282. https://doi.org/10.20956/halrev.v1n2.84 Mardani, Mardani, 'Hukum Islam Dalam Sistem Hukum Nasional', Jurnal Hukum E Pembangunan, 2008. https://doi.org/10.21143/jhp.vol38.no2.170

Mathew, Vloreen Nity, 'Acceptance on Halal Food among Non-Muslim Consumers', Procedia-Social and Behavioral Sciences, 121 (2014), 262-71. https://doi.org/10.1016/j.sbspro.2014.01.1127

Mohtar, Nor Marini, Nur Alia Amirnordin, and Hazliza Haron, 'Ayamas Food Corporation Sdn. Bhd: A Study on the Factors of Consumer Behaviour towards Halal Product Selection', Procedia-Social and Behavioral Sciences, 121 (2014), 166-85. https://doi.org/10.1016/j.sbspro.2014.01.1118

Muhamad, Nazlida, Vai Shiem Leong, and Normalisa Md Isa, 'Does the Country of Origin of a Halal Logo Matter? The Case of Packaged Food Purchases', Review of International Business and Strategy, 2017. https://doi.org/10.1108/RIBS06-2017-0049

Mustafa'Afifi, A H, M S Mohd Mahyeddin, M Kamilah Wati, Y Asming, SOSM Najib, A Asmidah, and others, 'Consumer Protection of Halal Products in Malaysia', Middle-East Journal of Scientific Research, 13 (2013), 22-28. https://doi.org/10.5829/idosi.mejsr.2013.16.s.10025

Mustafa 'Afifi Ab. Halim, and Mohd Mahyeddin Mohd Salleh, 'The Possibility of Uniformity on Halal Standards in Organization of Islamic Countries (OIC)', World Applied Sciences Journal, 17 (2012), 6-10. Google Scholar

Mustafar, Mohd Zaid, and Joni Tamkin Borhan, 'Muslim Consumer Behavior: Emphasis on Ethics from Islamic Perspective', Middle-East Journal of Scientific Research, 18.9 (2013),

1301-7.

https://doi.org/10.5829/idosi.mejsr.2013.18.9.12113

Nasution, Muhammad Dharma Tuah Putra, and Yossie Rossanty, 'Country of Origin as a Moderator of Halal Label and Purchase Behaviour', Journal of Business and Retail Management Research, $12.2 \quad$ (2018). https://doi.org/10.24052/JBRMR/V12IS02/COOAAMOHLAPB

Palil, Mohd Rizal, Ida Suriya Ismail, Nor Hazila Mohd Zain, and M.A. Anwar Abu Bakar, 'Social Enterprise and Taxation Policy: A Systematic Literature $\begin{array}{llll}\text { Review', } \quad \text { Bestuur, } & 9.2 & \text { 135-43. }\end{array}$ https://dx.doi.org/10.20961/bestuur.v9i2.55569

Pradana, Mahir, Rubén Huertas-García, and Frederic Marimon, 'Spanish Muslims'

Halal Food Purchase Intention', International Food and Agribusiness Management Review, $23.2 \quad$ (2020), 189-202. https://doi.org/10.22434/IFAMR2019.0200

Ramlan, Ramlan, and Nahrowi Nahrowi, 'Sertifikasi Halal Sebagai Penerapan Etika Bisnis Islami Dalam Upaya Perlindungan Bagi Konsumen Muslim', 
AHKAM: Jurnal Ilmu Syariah, $17.1 \quad$ (2014), 145-54. https://doi.org/10.15408/ajis.v17i1.1251

Raufu, A, and A Naqiyuddin, 'People's Awareness on Halal Foods and Products', Social and Behavioral Sciences, 2014, 3-25. https://doi.org/10.1016/j.sbspro.2014.01.1104

Rejaii, Mehdi, and Akram Arianfar, 'Halal Food: A Systemic Review', International Journal of PharmTech Research, 9.7 (2016), 340-45. Google Scholar

Rohmah, S, 'The Pattern of Absorption of Islamic Law into National Law: Study of the Halal Product Guarantee Law in the Perspective of Maqashid Shari'ah', Jurisdictie, 12.1 (2021), 20-47. https://doi.org/10.18860/j.v12i1.10521

Rusydiana, Aam Slamet, and Lina Marlina, 'Analisis Sentimen Terkait Sertifikasi Halal', JEBA (Journal of Economics and Business Aseanomics), 5.1 (2020). https://doi.org/10.33476/j.e.b.a.v5i1.1405

Said, Mahiah, Faridah Hassan, Rosidah Musa, and N A Rahman, 'Assessing Consumers' Perception, Knowledge and Religiosity on Malaysia's Halal Food Products', Procedia-Social and Behavioral Sciences, 130 (2014), 120-28. https://doi.org/10.1016/j.sbspro.2014.04.015

Sentani, Rachel Georghea, and Mathijs ten Wolde, 'The Legal Policy of Executability in the International Arbitral Tribunal Decision', Bestuur, 9.2 (2021), 144-55. https://dx.doi.org/10.20961/bestuur.v9i2.54451

Triasari, Devi, and Francesco De Zwart, 'The Legal Reform Policy on the Shariah Supervisory Board Role's in Indonesian Shariah Banks', Bestuur, 9.2 (2021), 113-25. https://dx.doi.org/10.20961/bestuur.v9i2.55173

Triyanta, Agus, Ni'matul Huda, and R Nazriyah, Hukum Ekonomi Islam: Dari Politik Hukum Ekonomi Islam Sampai Pranata Ekonomi Syariah (Yogyakarta: FH UII Press, 2012). Google Scholar

Wibowo, Mas Wahyu, and Fauziah Sheikh Ahmad, 'Non-Muslim Consumers' Halal Food Product Acceptance Model', Procedia Economics and Finance, 37 (2016), 276-83. https://doi.org/10.1016/S2212-5671(16)30125-3

Yunos, Rahimah Mohamed, Che Faridah Che Mahmood, and Nor Hafizah Abd Mansor, 'Understanding Mechanisms to Promote Halal Industry-the Stakeholders' Views', Procedia-Social and Behavioral Sciences, 130 (2014), 160-66. https://doi.org/10.1016/j.sbspro.2014.04.020 